\title{
PENTINGNYA PENDIDIKAN KEWARGANEGARAAN UNTUK MEMBANGUN KARAKTER ANAK DI MASA PANDEMI COVID-19
}

\author{
Rezy Vianthia Rendrapuri, Dinie Anggraeni Dewi $\bowtie$
}

Prodi Pendidikan Guru Sekolah Dasar, Universitas Pendidikan Indonesia Kampus Daerah Cibiru, Indonesia

\section{Info Artikel}

Sejarah Artikel:

Disubmit: Mei 2020

Direvisi: Juni 2021

Diterima: November 2021

\section{Keywords:}

Citizenship

Character,

Pandemic

\begin{abstract}
Abstrak
Di zaman sekarang ini banyak hal yang dapat mempengaruhi karakter anak dalam kehidupan berbangsa dan bernegara. Banyak anak anak tidak mengetahui sama sekali mengenai Pancasila, tokoh-tokoh nasionalisme dan bahkan lagu-lagu nasional. Maka dari itu, sangat penting menerapkan pendidikan kewarganegaraan dengan tujuan untuk menjaga dan mempertahankan Pancasila serta menumbuhkan sikap dan perilaku cinta tanah air, berjiwa demokratis, menjadi warga negara yang disiplin dan berpartisipasi aktif dalam membangun kehidupan. Di tambah keadaan saat ini, pandemi covid-19 ini memberikan dampak ke seluruh aspek kehidupan salah satunya ialah aspek pendidikan. Seluruh sekolah di Indonesia merubah sistem pembelajarannya dengan sistem pembelajaran daring. Pembelajaran daring ini akan membawa dampak pada sebuah urgensi pendidikan karakter anak dalam pembelajaran pendidikan kewarganegaraan. Tujuannya untuk memberikan informasi mengenai urgensi pendidikan kewarganegaraan dalam upaya membangun dan meningkatkan karakter anak di masa pademi covid-19. Metode yang digunakan dalam penulisan ini menggunakan metode literatur. Hasil dari pembahasan ini mengenai urgensi, pendidikan kewarganegaraan, karakter, dan pembelajaran daring di masa pandemi covid-19.
\end{abstract}

\begin{abstract}
In this day and age, many things can affect the character of children in the life of the nation and state. Many children don't know anything about Pancasila, nationalist figures and even national songs. Therefore, it is very important to implement civic education with the aim of maintaining and maintaining Pancasila and fostering attitudes and behaviors that love the country, have a democratic spirit, become disciplined citizens and participate actively in building life. In addition to the current situation, pandemic Covid-19. The pandemic Covid-19 has an impact on all aspects of life, one of which is the education aspect. All schools in Indonesia changed their learning system to an online learning system. This online learning will have an impact on the urgency of character education for children in learning civic education. The goal is to provide information about the urgency of civic education in an effort to build and improve the character of children during the Covid-19 pandemic. The method used in this writing uses the literature method. The results of this discussion urgency, civic education, character, and online learning during thepandemic Covid-19.
\end{abstract}




\section{PENDAHULUAN}

Manusia selalu mengalami perubahan dari waktu ke waktu. Perubahan karakter manusia dapat sangat mudah terpengaruh apalagi pada usia anak sekolah dasar. Setiap individu mengalami berbagai perkembangan, yang mengakibatkan munculnya perubahan, dimana perubahan karakter ini meliputi sikap dan perilaku anak. Dalam perkembangan dan perubahan karakter ini sangat dipengaruhi dari berbagai faktor, seperti faktor internal dan eksternal. Faktor internal seperti faktor genetik yang dapat diartikan sebagai potensi, baik secara psikis. Sedangkan Faktor eksternal adalah faktor lingkungan, faktor lingkungan ini merupakan yang turut membentuk dan berpengaruh terhadap karakter anak. Apalagi di zaman sekarang ini banyak pengaruh globalisasi dan banyak budaya asing dari luar yang masuk ke Indonesia.

Dengan begitu, di zaman sekarang ini banyak anak yang lebih mengenal budaya luar dibandingkan budaya bangsa Indonesia. Bahkan mereka tidak mengetahui mengenai apa itu Pancasila, tokoh-tokoh nasional dan lagu kebangsaan dan lagu-lagu nasional. Anak-anak di zaman sekarang lebih mengetahui tokohtokoh dalam sebuah permainan online serta lebih mengenal lagu-lagu idol K-pop ( lagu yang berasal dari Korea). Maka dari itu, sangat penting menerapkan pendidikan kewarganegaraan sejak usia dini dengan tujuan untuk menjaga dan mempertahankan Pancasila dan, budaya bangsa Indonesia itu sendiri serta menumbuhkan sikap dan perilaku cinta tanah air, bermoral, berjiwa demokratis, menjadi warga negara yang disiplin dan berpartisipasi aktif dalam membangun kehidupan. Seperti yang kita ketahui bahwa pendidikan ini sangatlah penting perannya dalam kehidupan, karena generasi berpendidikan mampu memajukan suatu bangsa, serta sebagai ujung tombak untuk mengetahui apa yang belum diketahui.

Pada saat ini pandemi Covid-19 menyerang seluruh negara di dunia, termasuk negara Indonesia. Pandemi yang saat ini sedang terjadi di berbagai penjuru dunia sangat berdampak pada seluruh aspek kehidupan yakni diantaranya aspek ekonomi, budaya, sosial bahkan Pendidikan. Pendidikan saat ini menggunakan metode pembelajaran daring. Dimana ini Sesuai dengan Surat Edaran Menteri Pendidikan dan Kebudayaan Nomor: 36962/MPK. Bahwa Seluruh kegiatan belajar mengajar di Indonesia dilaksanakan dengan pembelajaran daring. Pembelajaran daring ini dilakukan untuk memutus mata rantai penularan Virus Covid-19. ini dikarena wujud Virus Covid-19 sangat kecil dan tidak terlihat di seluruh kegiatan di berbagai tempat/negara terpaksa harus dikurangi bahkan dihentikan.

Pembelajaran daring ini tentu memanfaatkan kecanggihan teknologi seperti handphone, laptop, dll. Kecanggihan teknologi dapat berdampak positif dan juga negatif. Dampak negatifnya anak akan dengan mudah memainkan handphone dan sebagainya ini semakin mudahnya pengaruh luar masuk dan mempengaruhi karakter anak. Maka dari itu perlu dibarengi dengan pendampingan serta pemahaman kepada anak agar mereka tidak terbawa arus yang negatif dari globalisasi.

Orang tua dan guru memiliki peran besar terhadap karakter anak. Orang tua dan guru dapat mempengaruhi dalam akademiknya, tetapi juga mempengaruhi sikap anak terhadap pembelajaran sekolah dan pembelajaran secara keseluruhan, apalagi dalam pendidikan kewarganegaraan yang sangat penting dalam membangun karakter anak di masa pandemi ini.

Pendidikan kewarganegaraan adalah program pendidikan yang berintikan demokrasi politik yang diperluas dengan sumber-sumber pengetahuan lainnya, pengaruh-pengaruh positif dari pendidikan sekolah, masyarakat, orang tua,yang semuanya itu diproses guna untuk melatih para siswa untuk cinta tanah air dan tidak melupakan budaya nya sendiri, berpikir kritis, bersikap dan bertindak demokratis dalam mempersiapkan hidup yang berdasarkan Pancasila dan UUD 1945, dengan tujuan pendidikan kewarganegaraan ini untuk membentuk warga negara yang baik (good 
citizen). Diharapkan walaupun di masa pandemi ini siswa tetap belajar dengan baik meskipun menggunakan metode pembelajaran jarak jauh (daring), agar dapat menjadi generasi penerus bangsa Indonesia yang baik, berkarakter dan berbudi pekerti luhur.

\section{METODE}

Metode penelitian ini dibuat dengan menggunakan pendekatan kualitatif menggunakan metode literatur dengan penelitian deskriptif berdasarkan studi kasus dan telaah pustaka yang bertujuan untuk mengetahui bagaimana cara memperbaiki karakter moral dan nilai-nilai norma anak bangsa Indonesia dengan pembelajaran pendidikan kewarganegaraan . Data dari penelitian ini didapatkan dari berbagai buku elektronik, jurnal ilmiah, artikel ilmiah dan web lain yang telah dipastikan keakuratannya. Teknik analisis penelitian ini dilakukan dengan cara membandingkan serta menelaah satu per satu e-book atau jurnal terkait tentang pentingnya Pendidikan Kewarganegaraan. Hasil pencarian yang memenuhi kriteria kemudian dilakukan analisis artikel dan analisis terhadap murid sekolah dasar di lingkungan sekitar.

\section{TINJAUAN PUSTAKA}

\section{a. Pendidikan}

Definisi pendidikan dalam undangundang Republik Indonesia Nomor 20 Tahun 2003 tentang Sistem Pendidikan Indonesia Nasional Pasal 1 Ayat (1) : Pendidikan adalah usaha sadar dan terencana untuk mewujudkan suasana belajar dan proses belajar agar peserta didik secara aktif mengembangkan potensi dirinya untuk memiliki kekuatan spiritual keagamaan, pengendalian diri, kepribadian, kecerdasan, akhlak mulia, serta keterampilan yang diperlukan dirinya, masyarakat, bangsa dan negara.

Sedangkan, menurut para ahli seperti Langeveld memberikan pengertian bahwa pendidikan adalah usaha mempengaruhi, melindungi, serta memberikan bantuan yang tertuju kepada kedewasaan anak dengan kata lain membantu anak agar cukup mampu dalam melaksanakan tugas hidupnya sendiri tanpa bantuan orang lain. Dalam membimbing harus mengandung nilai-nilai luhur sesuai dengan karakter dan martabat kemanusian, dengan tujuan akhir pendidikan adalah adanya kemampuan dan kemandirian hidup peserta didik. Adapun menurut Crow \& Crow menyatakan bahwa pendidikan adalah pengalaman yang memberikan pengalaman yang memberi pengertian, insight dan penyesuaian bagi peserta didik sehingga anak dapat berkembang dan tumbuh.

Dari pengertian pendidikan sebelumnya, bahwa pendidikan merupakan usaha yang dilakukan secara sadar secara sistematis dan terarah. Usaha proses pendidikan tersebut dilakukan oleh orang yang mempunyai rasa tanggung jawab untuk membangun masa depan peserta didik. Adanya tujuan dari pendidikan yang ingin dicapai yaitu kedewasaan dan kemandirian serta mempunyai perilaku yang berbudi pekerti luhur.

\section{b. Pendidikan Kewarganegaraan}

Kewarganegaraan dalam bahasa Latin disebutkan "civis", selanjutnya dari kata "civis" ini dalam bahasa Inggris timbul kata "civic" artinya mengenai Warga Negara atau Kewarganegaraan. Dari kata "civic" lahir kata "civics", ilmu Kewarganegaraan dan civic education, Pendidikan Kewarganegaraan.

Pengertian lain didefinisikan oleh Merphin Panjaitan (1998), bahwa Pendidikan Kewarganegaraan adalah pendidikan demokrasi yang bertujuan untuk mendidik generasi muda menjadi Warga Negara yang demokratis dan partisipatif melalui suatu pendidikan yang diagonal. Menurut Azra (2000), Pendidikan Kewarganegaraan adalah pendidikan yang cakupannya lebih luas dari pendidikan demokrasi dan pendidikan Hak Asasi Manusia. Sementara itu, Zamroni 
(2001) berpendapat bahwa Pendidikan Kewarganegaraan adalah pendidikan demokrasi yang bertujuan untuk mempersiapkan warga masyarakat berpikir kritis dan bertindak demokratis, melalui aktivitas menanamkan kesadaran kepada generasi baru bahwa demokrasi adalah bentuk kehidupan masyarakat yang paling menjamin hak-hak warga masyarakat.

Adapun Soedijarto (1996) mengartikan Pendidikan Kewarganegaraan sebagai pendidikan politik yang bertujuan untuk membantu peserta didik untuk menjadi Warga Negara yang secara politik dewasa dan ikut serta membangun sistem politik yang demokratis. Dari definisi tersebut, semakin mempertegas pengertian civic education (Pendidikan Kewarganegaraan) karena bahannya meliputi pengaruh positif dari pendidikan di sekolah, pendidikan di rumah, dan pendidikan di luar sekolah. Jadi, Pendidikan Kewarganegaraan (civic education) adalah program pendidikan yang memuat bahasan tentang masalah kebangsaan, Kewarganegaraan dalam hubungannya dengan negara, demokrasi, Hak Asasi

Manusia dan masyarakat madani (civil society) yang dalam implementasinya menerapkan prinsip-prinsip pendidikan demokratis dan humanis. Cholisin (2000) menyatakan pendidikan kewarganegaraan sebagai pendidikan politik yang fokus materinya peranan warga Negara dalam kehidupan bernegara yang kesemuanya itu diproses dalam rangka untuk membina peranan tersebut sesuai dengan ketentuan Pancasila dan UUD 1945 agar menjadi warga Negara yang dapat diandalkan oleh bangsa dan Negara. Somantri (2001) juga mendefinisikan

Pendidikan

Kewarganegaraan sebagai program pendidikan yang berintikan demokrasi politik yang diperluas dengan sumbersumber pengetahuan lainnya, pengaruh positif dari pendidikan sekolah, masyarakat dan orang tua yang kesemua itu diproses guna melatih para siswa untuk berpikir kritis, analitis, bersikap dan bertindak demokratis dalam mempersiapkan hidup demokratis yang berdasar Pancasila dan UUD 1945. Dan yang terakhir Sapriya (2012) menyatakan Pendidikan Kewarganegaraan lebih dikenal sebagai program pendidikan untuk membangun karakter warga Negara dengan tujuan akhir agar ia menjadi warga Negara yang cerdas dan baik (to be smart and good citizens).

\section{c. Pandemi Covid-19}

Virus Corona atau severe acute respiratory syndrome coronavirus 2 (SARSCoV-2) adalah virus yang menyerang sistem pernapasan. Penyakit karena infeksi virus ini disebut Covid-19. Virus Corona bisa menyebabkan gangguan ringan pada sistem pernapasan, infeksi paru-paru yang berat, hingga kematian. Virus Corona adalah jenis baru dari coronavirus yang menular ke manusia. Walaupun lebih banyak menyerang lansia, virus ini sebenarnya bisa menyerang siapa saja, mulai dari bayi, anakanak, hingga orang dewasa, termasuk ibu hamil dan ibu menyusui. Infeksi virus Corona disebut Covid-19 (Coronavirus Disease 2019) dan pertama kali ditemukan di kota Wuhan, China pada akhir Desember 2019. World Health Organization (WHO) mengumumkan pada tanggal 11 Maret 2020 bahwa Covid-19 dinyatakan sebagai pandemi. Sampai saat ini ada 215 negara yang terjangkit virus corona. Indonesia adalah salah satu negara yang terjangkit Covid-19. Virus ini menular dengan sangat cepat, hanya dalam waktu beberapa bulan hampir semua negara terkena virus ini. Pandemi Covid-19 membawa pengaruh kepada semua lintas kehidupan, khususnya pendidikan. Akibat dari pandemi Covid-19, pelaksanaan sekolah dari taman kanakkanak hingga universitas di tutup. UNESCO mengatakan bahwa 300 juta murid terganggu kegiatan sekolahnya dan penutupan sekolah sementara akibat dari 
kesehatan dan krisis (Handoyo, 2020). Covid-19 membuat suatu uji coba terhadap pelaksanaan pendidikan secara daring yang dilakukan secara massal (Sun, Tang, \& Zuo, 2020).

\section{d. Pembelajaran Daring}

Untuk memutuskan mata rantai penyebaran COVID-19 diperlukan kerjasamanya semua pihak dalam mengatasinya (Pikiran-Rakyat.com, 2020), upaya yang dilakukan pemerintah adalah tidak berkerumun dalam keramaian, tidak pergi ke pasar, tempat perolahragaan, tempat budaya dan lain sebagainya. Serta masyarakat yang bekerja di kantor, diusahakan untuk melakukan pekerjaan di rumah saja (Work From Home). Begitu pun pada bidang pendidikan, pembelajaran dilakukan dirumah saja (Learning From Home). Learning From Home merupakan pengalaman pertama yang dilakukan secara massal di Indonesia. Banyak pelajar dan guru belum terbiasa dengan Learning From Home yang dilakukan secara daring (KBRI Hanoi, 2020).Surat edaran mengenai kebijakan sekolah saat pandemi yang diluncurkan oleh Menteri Pendidikan dan Budaya pun memberikan ketentuan, yakni proses pembelajaran dilaksanakan dari rumah untuk memberikan pembelajaran yang bermakna melalui pembelajaran daring atau jarak jauh (Mendikbud, 2020). Ciri dari pembelajaran online atau daring adalah integrasi teknologi dan inovasi yang ada didalamnya(Banggur \& Situmorang,2018). Tanggapan UNESCO sebagai lembaga yang bergerak di bidang pendidikan, sangat menyetujui pelaksanaan pembelajaran dengan menggunakan wadah daring upaya pembelajaran jarak jauh, sehingga pembelajaran dapat dijangkau oleh murid dimanapun berada. Perubahan dari pelaksanaan pembelajaran dalam kelas hingga pelaksanaan pembelajaran dalam jaringan ini, yang berperan sebagai aktor terpenting adalah guru dan pendidik, karena mereka adalah pengendali dalam proses pembelajaran (Bao, 2020; Brasilia Kvatadze, 2020).

Pengaplikasian pembelajaran daring ini adalah bukti dari revolusi industri 4.0, dimana pengaksesan teknologi tidak terbatas, sehingga memungkinkan pelaksanaan pembelajaran daring atau jarak jauh (Verawardina\& Jama, 2018).

\section{e. Karakter}

Istilah karakter dalam bahasa yunani dan latin, charassein yang artinya "mengukir corak yang tetap dan tidak terhapuskan" watak atau karakter merupakan perpaduan dari segala tabiat manusia yang bersifat tetap sehingga menjadi tanda khusus untuk membedakan orang yang satu dengan yang lain. Karakter akan terbentuk bila aktivitas dilakukan berulang-ulang secara rutin hingga menjadi suatu kebiasaan, yang akhirnya tidak hanya menjadi suatu kebiasaan saja tetapi sudah menjadi suatu karakter. Pendidikan karakter dapat diterapkan pada semua mata pelajaran. Setiap mata pelajaran yang berkaitan dengan norma-norma perlu dikembangkan dan dikaitkan dengan kehidupan sehari-hari. Konsep dasar pendidikan karakter tertuang dalam Permendikbud Nomor 23 tentang Penumbuhan Budi Pekerti tahun 2015. Penumbuhan Budi Pekerti (PBP) bertujuan: menjadikan sekolah sebagai taman belajar yang menyenangkan bagi siswa, guru dan tenaga kependidikan, menumbuh kembangkan kebiasaan yang baik sebagai bentuk pendidikan karakter sejak di keluarga, sekolah dan masyarakat, menjadikan pendidikan sebagai gerakan yang melibatkan pemerintah, pemerintah daerah, masyarakat dan keluarga, dan/ atau menumbuhkembangkan lingkungan dan budaya belajar yang serasi antara keluarga, sekolah, dan masyarakat. 


\section{PEMBAHASAN}

\section{Urgensi Pendidikan Kewarga Negaraan Bagi Bangsa Indonesia}

Pada masa pandemi ini anak belajar menggunakan metode pembelajaran daring,dimana mereka belajar tidak hanya bersumber dari guru dan orang tua saja tetapi juga bersumber dari internet. Namun, penggunaan kecanggihan teknologi ini belum dimanfaatkan dengan sebagaimana mestinya. Sangat disayangkan, anak-anak hanya mengetahui apa-apa yang sedang viral di sosmed tetapi mereka kurang mengetahui bahkan ada yang tidak tahu sama sekali mengenai Pancasila, Undang- Undang Dasar 1945, tokoh-tokoh nasional, lagu- lagu nasional dan bahkan lagu kebangsaanpun mereka kurang mengetahui. Padahal teknologi sekarang sudah sangat canggih dan dapat dimanfaatkan dengan sebaikbaiknya belajar. Bukan hanya belajar akademik tetapi juga pendidikan karakter agar anak-anak dapat menumbuhkan rasa cinta tanah air dan patriotisme, serta menjadi warga negara yang baik yang tidak meninggalkan identitas bangsa negaranya sendiri.

Pendidikan kewarganegaraan (Civic Education) merupakan suatu program pendidikan yang berisikan bahasan tentang masalah kebangsaan. Kewarganegaraan dalam hubungannya dengan negara, demokrasi, Hak Asasi Manusia dan masyarakat civil society yang dalam implementasinya menerapkan prinsipprinsip pendidikan demokratis dan humanis. Pendidikan kewarganegaraan di banyak negara ingin membentuk warganya agar menjadikan warga negara yang baik, guna mendukung keberlangsungan negara ini adalah tujuan umum dari. Pendidikan kewarganegaraan Di Indonesia menunjukkan bahwa pendidikan kewarganegaraan tidak lepas dari tujuan, tatanan, dan kepentingan komunitas politiknya, dalam hal ini kehidupan bangsa dan bernegara Indonesia. Di Dalam Peraturan Pemerintahan Nomor 32 Tahun 2013 tentang Standar Nasional Pendidikan Menyatakan bahwa pendidikan kewarganegaraan dimaksudkan untuk membentuk peserta didik menjadi manusia yang memiliki rasa kebangsaan dan cinta tanah air dalam konteks nilai dan moral Pancasila, kesadaran berkontribusi Undang-Undang Dasar Negara Republik Indonesia 1945, nilai dan semangat Bhinneka Tunggal Ika, serta komitmen Negara Kesatuan Republik Indonesia.

Selain itu, pendidikan kewarganegaraan adalah membentuk warga negara nya agar menjadi baik (good citizen). Dalam mempelajari pendidikan kewarganegaraan ini mempunyai fungsi yaitu agar semua peserta didik memahami hakikat pendidikan kewarganegaraan dalam rangka pengembangan kemampuan yang utuh, agar pserta didik mempunyai rasa cinta globalisasi, berjiwa nasionalisme, dan juga bermoral agar tidak mudah tterpengaruh oleh dampak tanah negatif dalam berbagai kondisi. Baik sedang pandemic atau tidak tetaplah penting untuk menerapakan pendidikan kewarganegaraan.

Komunitas internasional. National Council for the Social Studies (NCSS) berpendapat dan menyebut bahwa tujuan dari pendidikan kewarganegaraan adalah sebagai berikut.

a. Agar warga negara dapat memiliki pengetahuan serta keterampilan untuk pemecahan masalah yang terjadi sekarang maupun masa yang akan datang dengan dihadapi secara dewasa.

b. Warga negara memiliki kesadaran adanya pengaruh sains dan teknologi terhadap peradaban serta mampu memanfaatkannya untuk memperbaiki nilai kehidupan yaitu dengan cara memanfaatkan teknologi secara baik, benar dan bijak.

c. Warga negara menyadari bahwa mereka hidup dalam dunia yang terus berkembang, yang membutuhkan kesediaan untuk menerima fakta baru, gagasan baru, serta tata cara hidup yang baru.

d. Warga negara dapat berperan serta dalam proses pembuatan keputusan melalui pernyataan pendapat kepada wakil - wakil rakyat, para pakar dan para spesialis.

e. Warga negara memiliki keyakinan terhadap kebebasan individu serta persamaan hak bagi setiap orang yang dijamin oleh Konstitusi. 
f. Warga negara memiliki kebanggaan terhadap prestasi bangsa, penghargaan terhadap sumbangan yang diberikan bangsa lain serta dukungan untuk perdamaian serta kerjasama.

g. Warga negara mampu memanfaatkan seni yang kreatif untuk meningkatkan perasaan terhadap pengalaman manusia yang universal serta pada keunikan individu.

h. Mempersiapkan warga negara yang mampu menentukan pilihan yang tepat diantara berbagai macam alternatif yang terdapat dalam suatu masyarakat.

Selain Itu tujuan dari mempelajari pendidikan kewarganegaraan ini adalah, sebagai berikut:

a. Dapat memperlihatkan karakter yang mencerminkan penghayatan, pemahaman, dan pengamalan nilai-nilai Pancasila dan moral secara personal dan sosial.

b. Mempunyai komitmen konstitusional yang ditopang oleh sikap positif dan pemahaman utuh tentang Undang-Undang Dasar Negara Republik Indonesia Tahun 1945.

c. Diharapkan bahwa warga negara Indonesia dapat berpikir secara kritis, rasional, dan kreatif serta memiliki semangat kebang saan dan cinta tanah air yang dijiwai oleh nilainilai Pancasila, Undang Undang Dasar Negara Republik Indonesia Tahun 1945, semangat Bhinneka Tunggal Ika, dan komitmen Negara Kesatuan Republik Indonesia.

d. Berpartisipasi secara aktif, cerdas, dan bertanggung jawab sebagai anggota masyarakat, tunas bangsa, dan warga negara sesuai dengan harkat dan martabatnya sebagai makhluk ciptaan Tuhan Yang Maha Esa yang hidup bersama dalam berbagai tatanan sosial kultural.

Dalam Standar Isi Pendidikan Kewarganegaraan sebagaimana tertuang dalam Permendiknas No. 22 Tahun 2006 tentang Standar Isi, mata pelajaran Pendidikan Kewarganegaraan merupakan mata pelajaran yang memfokuskan pada pembentukan Warga Negara yang memahami dan mampu melaksanakan hak-hak dan kewajibannya untuk menjadi Warga Negara Indonesia yang cerdas, terampil, dan berkarakter yang diamanatkan oleh Pancasila dan UUD 1945.

Menurut Margaret Stimmann Branson (1998), terdapat 3 (tiga) komponen utama yang perlu dikuasai dalam belajar Pendidikan Kewarganegaraan. Ketiga komponen utama Pendidikan Kewarganegaraan itu adalah:

a. Pengetahuan kewarganegaraan (civic knowledge), Civic knowledge berkaitan dengan isi atau apa yang harus warga negara ketahui.

b. Keterampilan kewarganegaraan (civic skills), Civic skills merupakan keterampilan apa yang seharusnya dimiliki oleh warga negara yang mencakup keterampilan intelektual dan keterampilan partisipasi.

c. Sikap kewarganegaraan (civic disposition), Civic disposition berkaitan dengan karakter privat dan publik sari warga negara yang perlu dikembangkan dan dipelihara dalam kehidupan bernegara.

\section{Upaya Meningkatkatkan Karakter Anak Di Masa Pandemi Covid-19}

Pendidikan karakter ini merupakan suatu sistem penanaman nilai-nilai karakter (nilai, pendidikan budi pekerti, pendidikan moral, pendidikan watak) yang bertujuan mengembangkan kemampuan seluruh warga sekolah untuk memberikan keputusan baikburuk, keteladanan, memelihara apa yang baik dan mewujudkan kebaikan itu dalam kehidupan sehari-hari dengan sepenuh hati pada anak agar dapat mengetahui pemahaman mereka bilamana dalam belajar dan pengalaman apa saja yang diperoleh selama melakukan kegiatan pembelajaran, pengembangan karakter anak bangsa juga dapat dilakukan melalui pengembangan karakter bangsa dapat dilakukan melalui pendidikan kewarganegaraan yang dimana perkembangan anak secara individu melalui pengalaman yang telah didapatkan melalui rumah,sekolah, dan di masyarakat.

Pendidikan karakter selalu diterapkan sejak dini oleh orang tua dan guru yang mengajar 
di sekolah. Karena banyak hal yang dapat diambil dari pendidikan karakter dirumah maupun disekolah.

Dengan tujuan pendidikan karakter adalah untuk membentuk penyempurnaan diri individu secara terus-menerus dan melatih kemampuan diri demi menuju kearah hidup yang lebih baik. Pendidikan karakter di sekolah sangat berkaitan dengan pendidikan kewarganegaraan. Pendidikan karakter sangatlah penting dalam dunia pendidikan terutama bagi anak-anak, karena pendidikan karakter ini dijadikan sebagai wadah atau proses untuk membentuk pribadi yang lebih baik.

Namun, sejak adanya pandemi Covid19 ini, pendidikan di indonesia beralih melalui sistem daring (online) atau tidak tatap muka. Bahkan Kementerian Pendidikan dan Kebudayaan (Kemendikbud) telah merumuskan konsep sekolah pendidikan karakter, yang setidaknya ada lima karakter yang harus ditanamkan pada peserta didik. Yaitu: Membentuk nilai nasionalisme, integritas, kemandirian, gotong royong dan religius. Dengan adanya pandemic Covid-19 ini membuat kehidupan serta aktivitas sehari hari terhalang, baik di masyarakat bahkan dalam aspek pendidikan, dengan diterapkannya pembatasan anak pada tempat umum dan belajar dirumah, berbagai aktivitas peserta didik terganggu dalam kegiatan sekolah. Meskipun demikian, adanya masa pandemic ini kita harus tetap memperhatikan pendidikan untuk anak sebagai penerus bagi masa depan bangsa. Di masa pandemi Covid-19 ini, dimana peserta didik mendapatkan pendidikan tidak secara langsung oleh tenaga pendidik melainkan dari rumah masing-masing. Peserta didik pun tidak bisa bertemu dengan teman-temannya untuk belajar bersama. Hal ini dapat sangat menyusahkan dan menyedihkan bagi anak didik dan para tenaga pendidik karena harus pembelajaran secara daring, menggunakan media online seperti di whatsapp, zoom atau aplikasi untuk belajar lainnya.

Banyak orang yang mengabaikan pentingnya pendidikan karakter, padahal karakter akan terbentuk saat anak masih kecil dan akan membuat anak saat dewasa menjadi anak yang terbentuk karakter yang sesungguh nya sudah terbentuk saat sejak kecil apalagi dengan kondisi sekarang ini, dimana hampir semua negara mengalami pandemi Covid-19 . untuk meningkatkan karakter anak pada masa pandemi Covid-19 ini ada beberapa upaya yaitu sebagai berikut:

a. Guru dan orang tua memiliki peran yang sangat pentng untuk mengembangkan karakter anak agar anak memiliki karakter yang baik. Seperti yang dicetuskan oleh $\mathrm{Ki}$ Hajar Dewantara, bahwa perilaku guru dalam mendidik anak harus mempunyai metode yang tepat. Dalam konsep pemikiran Ki Hajar Dewantara ini ada beberapa konsep yang paling terkenal yaitu semboyan Ingarso tung tulada, yang mempunyai arti bahwa sosok gur dapat mengajarlkan anak/ peserta didik dari depan. Ingarso Madya Mangun Kasro. Yang artinya bahwa seorang guru dapat menuntun anak di bagain tengah, dengan begitu dapat memitivasi anak agar untuk selalu bersemangat.dan Tut Wuri Handayani yang berarti guru di belakang memberikan dorongan dari belakanng, bahwa siswa di arahkan agar berani bertanggung jawab. oleh gurunya pendidikan perilaku kolaborasi antara peserta didik agar terus selalu terjalin dalam kondisi apapun, apalagi dalam kondisi pandemic saat ini. Saat ini seorang guru sangat membutuhkan orang tua untuk membantu mendidik anak mereka karena pendidikan karakter ini tidak hanya diberikan oleh orang tua tetapi oleh guru juga, namun saat ini orangtua memiliki peran yang sangat penting dalam membangun dan meningkatkan karakter anak agar tidak terbawa oleh arus negatif globalisasi. Dalam pengimplementasiannya orang tua dan guru agar dapat membimbing keteraturan dan kedisiplinan ketika proses belajar, juga memotivasi anak dalam belajar dan menjadi fasilitator yang baik bagi anak dalam belajar. Tentu ini akan berpengaruh anak akan lebih terbimbing. Selain dari ilmu pengetahuan, 
karakter jauh lebih penting. Jika hanya pintar namun tidak memiliki karakter yang baik akan percuma saja, karena bangsa Indonesia sangat membutuhkan generasi yang memiliki karakter yang sejalan dengan UndangUndang Dasar 1945 dan Pancasila sebagai jati diri bangsa Indonesia. Masa pandemi ini menjadikan pendidikan yang pertama dan utama adalah di rumah. Belajar dari pandemi, guru, orang tua dan masyarakat harus bersinergi gotong royong membangun pendidikan.

b. Adapun menurut Shoimin (2014:230) menyatakan Problem Based Learning merupakan suatu model pembelajaran yang melibatkan peserta didik untuk memecahkan suatu masalah melalui tahap-tahap metode ilmiah. Problem Based Learning ini adalah pembelajaran yang dilakukan oleh siswa untuk mengatasi suatu masalah dengan keputusannya sendiri diikuti oleh lingkungan sekitarnya. Jadi disini yang berperan mendidik peserta didik adalah lingkungan dan dirinya sendiri. Lingkungan sangat berpengaruh dalam mengembangkan diri, jika lingkungan yang sehat akan membawa dampak yang baik. Problem Based Learning dikaji dan digali untuk diaktualisasikan dalam pembelajaran, sehingga nilai karakter tersebut ditanamkan atau diinternalisasikan ke dalam diri peserta didik. Artinya, Problem Based Learning dapat mengisi nilai karakter dari luar yang sesuai kepentingan pendidik dalam pembelajaran.

c. Pemanfaatan Teknologi Informasi dan Komunikasi. Dengan berkembangnya teknologi di zaman sekarang ini, kita dapat mengimbangi keperluan kita untuk berkomunikasi, belajar dan melakukan aktivitas lainya tanpa harus bertemu secara langsung. Nah ini yang dilakukan saat ini dikarenakan sedang pandemi. Dalam pembelajaran secara daring ini kementrian memberikan metode belajar dalam masa pandemi Covid-19 ini dengan menggunakan metode yang berbasis teknologi yang mengharuskan lembaga pendidikan, guru, siswa bahkan orang tua agar cakap teknologi. Segala informasi diwakili oleh komputer yang terhubung ke internet sebagai media utama telah mampu memberikan kontribusi yang begitu besar bagi proses pendidikan.

Dengan demikian teknologi informasi ini sangat berguna untuk kehidupan pada situasi pandemi sekarang. Dengan teknologi kita bisa melakukan apapun yaitu bekerja, sekolah dan lain sebagainya. Guru dapat menyampaikan materi dengan metode yang interaktif dan interaktif sehingga dapat mengembangkan kreativitas siswa sehingga mampu mengeksplor dirinya sendiri agar anak menemukan karakternya, dan mampu menerapkan nilai -nilai dari pendidikan kewarganegaraan ini bagi kehidupan generasi untuk kedepannya agar dapat memajukan bangsa dan negara Indonesia kearah yang lebih baik.

Sejalan dengan perkembangan Unessco, pembanguan pendidikan nasional Indonesia seutuhnya terteuang dalam buku kurikulum 2013. Adapun tujuan dari kurikulum 2013 yakni, : Kopetensi sikap spiritual, sikap sosial, penetahuan dan keterampilan. Meskipun kita belajar dan mengajar dari jarak jauh tetapi kita harus selalu bahagia.

\section{SIMPULAN}

Pendidikan kewarganegaraan (Civic Education) merupakan program pendidikan yang memuat bahasan tentang masalah kebangsaan. Kewarganegaraan dalam hubungannya dengan negara, demokrasi, Hak Asasi Manusia dan masyarakat madani (civil society) yang dalam implementasinya menerapkan prinsip-prinsip pendidikan demokratis dan humanis. Tujuan umum dari semua pendidikan kewarganegaraan ini adalah membentuk warganya agar menjadi warga negara yang baik, guna mendukung keberlangsungan negara Indonesia agar warga negaranya memiliki karakter, sikap dan perilaku yang berbudi pekerti luhur serta cinta tanah air. Apalagi di zaman sekarang ini dari hasil pengamatan banyak anak yang tidak mengetahui 
apa itu Pancasila, siapa saja tokoh bersejarah di Indonesia, bahkan lagu-lagu kebangsaanpun mereka kurang hapal . anak jaman sekarang lebih mengetahui kebudayaan asing seperti tokohtokoh yang ada di game online, lagu-lagu K-Pop, dll. Maka dari itu untuk mempertahankan dan membungan karakter anak yang cinta tanah air, berbudi pekerti luhur, demokratis dan ikut serta dalam menjaga dan mempertahan Pancasila sebagai pedoman bangsa serta Undang-Undang Sebagai hukum tertinggi di Indonesia.

Dengan mengetahui pentingnya pendidikan kewarganegaraan ini bagi kehidupan generasi untuk kedepannya agar dapat memajukan bangsa dan negara Indonesia kearah yang lebih baik. Pendidikan kewarganegaraan ini sangat berkaitan dengan karakter maka dari itu adanya pendidikan karakter yang sangat penting untuk membentuk karakter peserta didik melalui pendidikan karakter yang merupakan suatu upaya untuk kembali membangkitkan serta membekali peserta didik agar memiliki karakter yang baik,yang telah dijelaskan dalam pendidikan kewarganegaraan.

Dengan cara menumbuhkan keterampilan gerakan literasi yang tinggi, mampu memiliki kemampuan dalam berpikir kritis dan aktif, kreatif walaupun harus belajar di rumah. Dalam meningkatkan pendidikan kewarganegaraan saat ini sebagai guru dan orang tua perlu diberikan pengarahan agar mampu membimbing anak dalam pembelajaran daring ini. Bukan hanya dalam aspek ilmu pengetahuan tetapi harus diperhatikan juga karakter anak. Guru harus paham betul mengenai karakter anak, karena sejatinya anak-anak adalah harta yang paling berharga untuk bangsa dan negara. Maka dari itu, anak harus diberikan pengetahuan mengenai pendidikan kewarganegaraan yang mencakup nilai dan moral serta rasa nasionalisme. Guru dan juga orang tua diberikan pemahaman bagaimana teknik dan strategi dalam pendidikan karakter pada pembelajaran daring yang belajar dari rumah. Selain itu, guru juga berusaha kreatif dalam menggali informasi dan karakteristik peserta didik dalam menentukan model-model pembelajaran dengan hasil belajar yang diharapkan pada pembelajaran daring.

\section{DAFTAR PUSTAKA}

Ahmad, S.(2020). "Penerapan Model Pembelajaran Problem Based

Learning (PBL) "Pada Masa Pandemi Covid 19 Dalam Meningkatkan Aktivitas Dan Hasil Belajar Siswa Pada Mata Pelajaran Produk Kreatif Dan Kewirausahaan". Seminar Nasional Manajemen, Ekonomi dan Akuntansi Fakultas Ekonomi dan Bisnis UNP Kediri.

Aji, T. (2020) "Pendidikan Karakter di Masa Pandemi" BDK Jakarta Jakarta Timur.

Branson, M. (1998). "Pendidikan Kewarganegaraan". Indonesia

Fauzi, I. (2013). "Pendidikan Kewarganegaraan (Civil Education)".

Superior Pusat Studi Pemberdayaan Rakyat dan Transformasi Sosial. Jember

Fransiska, D. (2014) . "Sikap Nasionalisme". Universitas Pendidikan

Indonesia. Bandung

Umar, M. (2015). " Peran Orag Tua dalam peningkatan Prestasi belajar anak" . Jurnal Edukasi". Indonesia.

Kemendiknas. (2011). "Panduan Pelaksanaan Pendidikan Karakter".

Badan Penelitian dan Pengembangan Pusat Kurikulum dan Perbukuan. Jakarta

Kemendiknas. (2011). "Panduan Pelaksanaan Pendidikan Karakter".

Badan Penelitian dan Pengembangan Pusat Kurikulum dan Perbukuan.Jakarta

Permendiknas Tahun 2006 No. 22 Tahun 2006 tentang Standar Isi, mata pelajaran Pendidikan Kewarganegaraan.

Omeri, N. (2015). "Pentingnya Pendidikan karakter dalam dunia pendidikan". Manajer Pendidikan, 9(3) 464-468.

Prapowo. (2020) . " Peran Orang Tua dalam Karakter Anak ".Jurnal Pendidikan Islam." Indonesia.

Putri, S. (2020). "Pendidikan Karakter di situasi Pandemi" . Universitas Riau. Riau 
Undang-Undang Republik Indonesia Nomor 20 Tahun 2003 Tentang Sistem Pendidikan Nasional

Suharti. L. (2017) . " Bentuk Karakter Anak “ Kemdikbud. go.ig

Wahab, A. A. dan Sapriya. (2011). "Teori dan Landasan Kewarganegaraan". ALFABETA.
Wiloati, D. (2014)

"Pendidikan Kewarganegaraan". CV. Maulana Media Mardika, Bandung

Winarno. (2020). "Paradigma Baru Pendidikan Kewarganegaraan". Bumi Aksara. Jakarta.

Wiryoprantono. H, (2017). “ Ki Hajar Dewantara- pemikiran-perjuangannyapemikiran dan perjuangan". Tim museum Kebangkitan Nasional. 